\title{
Městská kolejová doprava v Ostravě a vznik komunálního dopravního podniku (1945-1949)
}

\section{MICHAELA ZÁVODNÁ}

Závodná, Michaela: Urban Rail Transport in Ostrava and the Establishment of a Municipal Transport Company (1945-1949)

The present study focuses on the establishment of the Ostrava municipal transport company. It captures post-war changes in the management of smaller firms that were incorporated into this municipal company. It also pays attention to the process of nationalization and monitors its course and impacts on the transport network in Ostrava. Furthermore, it presents problems faced by the administration which were related to the different legal nature of the firms and their different provincial classification. Finally, it also describes the negotiations on the establishment of municipal enterprises at various levels of government.

Key Words Urban Transport; Trams; Ostrava; Nationalization; Municipal Enterprise; 1945-1949

doi.org/10.15452/Historica.2020.11.0012

Contact Ostravská univerzita; michaela.zavodna@osu.cz

\section{Úvod}

Období let 1945-1949/1950 výrazným způsobem zasáhlo nejen do podoby dopravního podnikání na Ostravsku. Postupná konsolidace dopravních poměrů spolu s postupným odklonem od demokratického k totalitárnímu systému, vrcholícímu únorem 1948 a nastolením komunistického režimu, se výrazně projevila také na Ostravsku. Komplikovaný systém tvořený zemskými i městskými dopravními podniky, rozprostírajícími se ve dvou zemích a využívající dva odlišné rozchody kolejnic, neunikl pozornosti samosprávných orgánů. Vznik komunálního dopravního podniku města Ostravy v roce 1949 sice představoval částečné sjednocení dopravních potřeb oblasti, vedla k němu však obtížná a dlouhá cesta, završená až v roce 1953, kdy se stala součástí podniku i trat' Vítkovických železáren Klementa Gottwalda. Předkládaná studie se pokouší zachytit v základních rysech tento doposud nepřiliš zmapovaný proces. Pozornost věnuje především legislativní rovině a její aplikaci na konkrétní historickou látku, dále sleduje vztah mezi jednotlivými národními výbory a ministerstvy, stranou pozornosti není ani vztah mezi dopravními firmami samotnými. S ohledem na charakter dosavadního stavu poznání této problematiky byly využity primárně archivní fondy uložené v Zemském archivu v Opavě a v Archivu

Tato studie byla zpracována v programu NAKI II v rámci řešení projektu s názvem VELKÝ HISTORICKÝ ATLAS ČESKÉHO SLEZSKA - identita, kultura a společnost českého Slezska v procesu společenské modernizace s dopadem na kulturní krajinu, reg. č. DG18P02OVV047, řešeného na Filozofické fakultě Ostravské univerzity. 
města Ostravy ${ }^{2}$ s tím, že řada aspektů zůstala stranou pozornosti, nebot' svým rozsahem přesahuje stránkové možnosti této studie.

\section{Poválečný vývoj}

Situace městské kolejové dopravy na Ostravsku po skončení první světové války byla zcela pochopitelně chaotická a nepřehledná. Nejednalo se jen o provizorní obnovení provozu na ostravských tratích, ${ }^{3}$ ale především o konsolidaci technických i personálních poměrů u dopravních firem v politicky nově uspořádaném státu, což se ukázalo na jedné straně jako klíčové, na druhé straně jako poměrně problematické. Nejvýrazněji se změny projevily především ve vedení Společnosti moravských místních drah, a to jak personálně, tak provozně. V čele této akciové společnosti s majoritou města Moravská Ostrava stála správní rada, která se s koncem druhé světové války rozpadla. Aby bylo možné zajistit fungování podniku, navrhl ředitel firmy ing. Viktor Fiala presidiu Místního národního výboru statutárního města Ostrava ${ }^{4}$ již 6 . června 1945, aby agendu správní rady dočasně převzali jeho tři členové, konkrétně předseda Josef Kotas a dále Jaroslav Pavlán a Bohumil Rolek. Za závodní výbor firmy byl poté pověřen členstvím František Rokovanský, předseda tohoto výboru a současně tajemník dopravní firmy. Jeho náhradníkem se měl stát přednosta dopravy a člen závodního výboru Rudolf Kucharský. ${ }^{5}$ Dne 16 . července 1945

\footnotetext{
2 V Archivu města Ostravy (dále AMO) byly excerpovány fondy: Ústřední národní výbor Ostrava 1945-1949 (dále ÚNV), především plenární zápisy, dále fond Jednotný národní výbor v Ostravě (1912) 1949-1957 (1971) (dále JNV), zde především zápisy rady, pléna a spisy ke vzniku komunálních podniků. Ke vzniku a fungování dopravního podniku byly využity také př́islušné materiály uložené ve fondu Ředitelství městských komunálních podniků Ostrava 1949-1953 (dále ŘMKP), k vlastnímu fungování akciové společnosti fond Společnost moravských místních drah Moravská Ostrava 1886-1949 (1950) (dále SMMD). Fond Místní dráha Moravská Ostrava - Karviná neobsahuje využitelné informace, dosud nezpracovaný fond Dopravní podnik Ostrava, a. s. (1922) 1949-2010 (dále DPO), do kterého mi bylo umožněno díky vstř́icnosti zaměstnancủ Archivu města Ostravy nahlédnout, obsahuje primárně technické, stavební a provozní záležitosti dopravního podniku a pro téma této studie je nepoužitelný. Analýze byly dále podrobeny fondy v Zemském archivu v Opavě, konkrétně fond Moravskoslezský zemský národní výbor, expozitura Ostrava (1888) 1945-1949 (1951) (dále MZNV, exp. O) který obsahoval především zápisy z rady tohoto orgánu v letech 1945-1949; dále fond Severomoravský krajský národní výbor Ostrava (1834) 1945-1991 (1992) (dále Sm KNV Ostrava), kde lze nalézt jak zápisy z rady KNV, tak spisový materiál k obecným dopravním otázkám kraje i k otázce vzniku krajských komunálních podniků vč. otázek zůstatkové majetkové podstaty Země moravskoslezské. K majetkovým otázkám převodu bohumínských a slezských zemských drah lze částečně využít rovněž fond Slezské zemské dráhy Bohumín (1885) 1910-1949 (1952) (dále SZD Bohumín). Zde jsou uloženy rovněž důvodové zprávy k těmto drahám, na které odkazují zápisy ze zasedání Moravskoslezského zemského národního výboru.
}

3 Doprava byla obnovena již 8. 5. 1945 na 4,3 km dlouhém úseku mezi Př́ívozem a Vítkovicemi a do konce května již byly v provozu všechny dosažitelné úseky ve vnitřním městě. Do června se podařilo zprovoznit i trat' do Kyjovic-Budišovic. AMO, fond SMMD, inv. č. 27, opisy zápisů ze schůzí správních rad od 16. 7.1945 do 21. 1. 1948, zápis z 16.7.1945.

4 Správní vývoj města Ostravy ve sledovaném období popsal ve svých studiích Karel Jiř́ik. JIŘíK, Karel: Vývoj organizace a působnosti národních výboru v Ostravě. In: JIŘ́lK, Karel a kol.: Ostrava socialistická : Sborník studií k výstavbě města v letech 1945-1970. Ostrava 1971, s. 283-328. Publikace sice byla vydána v nákladu 2000 kusů, avšak s ohledem na Jiř́kovy politické postoje v roce 1968 byla její distribuce zakázána. K tématu se Jiřík vrátil v 80. letech 20. století, srov. např. JIŘíK, Karel: Správní a územní vývoj města Ostravy. In: JIŘíK, Karel (red.): Ostrava : Př́spěvky k dějinám a současnosti Ostravy a Ostravska, 13. Ostrava 1985, s. 74-126.

5 Josef Kotas vystř́idal dosavadního správního radu Štěpána Hajného. AMO, fond ÚNV, inv. č. 5, sign. XXII, kart. 1. V současné době, tj. květen 2020, dochází k reinventarizaci fondu, k dispozici je prozatímní inventář a dohledávání probíhalo dle signatury a označení referátu (dopravní). 
na prvním poválečném setkání správní rady proběhla volba jejího předsedy, kterým se stal Josef Kotas, dále místopředsedy a členů výkonného výboru. ${ }^{6}$

Společnost moravských místních drah se vlivem poválečných okolností dostala velmi rychle do dvou vleklých majetkových sporů. Tím prvním byla otázka vlastnictví obchodního a obytného domu Nesselroth č. p. 492 na parcele č. 402/10 v Moravské Ostravě, který byl koncem války částečně vypálen. ${ }^{7}$ Společnost jej zakoupila v průběhu listopadu 1943 za 3,5 mil. korun od Doris Rennerové, bytem ve vídeňském XIX. okresu. ${ }^{8}$ V lednu roku 1946 dostala správní rada dopis od Jakuba Nesselrotha, který tvrdil, že smlouva z roku 1939 (sic!) je neplatná, nebot' byla uzavřena pod nátlakem gestapa. Dále požadoval dostavbu budovy dle původních plánů z roku 1928 s vyvěšením cedule ve znění Oprava obchodního domu fy Jakub Nesselroth, Mor. Ostrava, ${ }^{9}$ následně zvažoval soudní spor a v únoru 1946 byl ochoten od něj ustoupit v případě, že mu firma přenechá jiný vhodný objekt, např. své prozatímní ředitelství v budově tzv. staré pošty na Těšínské ulici $14 .{ }^{10}$ Celý spor se podařilo vyřešit až v roce 1949 odstupným ve výši jednoho milionu korun, které tehdy již komunální podnik zaslal na příslušný účet. ${ }^{11}$

Mnohem zásadnějšímu problému však čelila společnost v př́ípadě normálně rozchodné parní dráhy ze Svinova do Kyjovic-Budišovic a úzkorozchodných tratí ze Slezské Ostravy do Hrušova a do Michálkovic, které během okupace zakoupila od Moravskoslezských zemských drah. ${ }^{12}$ Závodní výbory dvou posledně jmenovaných tratí odmítly začlenění do závodního výboru Společnosti moravských místních drah a pověřily někdejšího ředitele zemských drah, aby společnosti oznámil, že zpětně od 1. května 1945 jsou dráhy opět v zemském provozu, nebot' smlouvy jsou neplatné, a to s dovoláním se na dekret prezidenta republiky z 19. května 1945 č. 5, o neplatnosti některých majetkově-právních jednání z doby nesvobody a o národní správě majetkových hodnot Němců, Madiarů, zrádců a kolaborantů a některých organisací a ústavů. ${ }^{13}$

Tento krok následně potvrdil i Moravskoslezský zemský národní výbor se svou expoziturou v Moravské Ostravě dne 14. srpna 1945. ${ }^{14}$ Za neplatné byly prohlášeny př́slušné kupní smlouvy z roku 1942 a 1943, které se týkaly majetku bývalých Slezských zemských drah. Dráhy tak měly přejít zpět do vlastnictví země s tím, že by je dočasně provozovala jako doposud Společnost moravských místních drah a následně, po dohodě s ministerstvem dopravy, by je převzaly Československé dráhy. Zrušení kupních smluv

\footnotetext{
$6 \quad$ Místopředsedou byl zvolen Karel Sochorek a členy výkonného výboru Rudolf Kucharský, Antonín Vavroš a Bohumil Rolek. AMO, fond SMMD, inv. č. 27, zápis z 16. 7. 1945.

7 Jedná se o prostor pasáže na ulici Denisova v Ostravě. Budova byla částečně vypálena v noci z 30. 4. na 1. 5. 1945 a zůstala jen věžní část s pasáží a schodištěm. Tamtéž.

$8 \quad$ První kupní smlouva byla uzavřena dne 29.9.1938 s paní Ruth Barnerovou z Hallu. Z dosud prostudovaných materiálů však není zřejmé, zda se jednalo o spolumajitelku, či předchozí majitelku. AMO, fond SMMD, inv. č. 27, zápis z 16. 7. 1945; tamtéž, inv. č. 376, Výroční zpráva správní rady podaná na valné hromadě za léta 1941-1948, konkrétně výroční zpráva Společnosti moravských místních drah daná na 58. řádné valné hromadě akcionářů dne 28.12. 1945 .

AMO, fond SMMD, inv. č. 27, zápis z 25. 1. 1946.

10 Tamtéž, zápis z 5. 2. 1946.

11 Tamtéž, inv. č. 34, Zápisy schůzí likvidačního výboru 22. 7. 1948-7. 7. 1949, zápis z 26. 2.1949.

12 K historii těchto tratí za okupace např. GARBA, Karel: Úzkorozchodné dráhy na Ostravsku 1902-1973, I. Ostrava 1974, s. 121-135.

13 AMO, fond SMMD, inv. č. 33, zápis z 14. a 16. 7. 1945.

14 ZAO, fond MZNV, exp. O, inv. č. 804, kart. 829.
} 
a návrat tratí zemi poté stvrdil výměr Moravskoslezského zemského národního výboru z 10. listopadu 1945, č. j. VII-12/2. ${ }^{15}$

Tuto interpretaci a požadavek samozrejmě společnost odmítla. $\mathrm{V}$ začátcích sporu poukazovala na to, že $\mathrm{k}$ př́slušnému dekretu doposud nebylo vydáno prováděcí nařízení, ${ }^{16}$ a argumentovala současně tím, že Společnost moravských místních drah nebyla podnikem německým,${ }^{17}$ nepodléhá tedy ustanovení zmíněného dekretu, a že dráhy řádně zakoupila a kupní cenu v termínech zaplatila. ${ }^{18}$

Do probíhajícího sporu o vlastnictví dráhy z Vřesiny do Kyjovic-Budišovic se zapojily také okolní obce, resp. jejich národní výbory. Na veřejné schůzi dne 17. února 1946 byl domluven další postup a požadavky, které byly formou memoranda zaslány ostravským ústředním orgánům. Národní výbory Velké a Pusté Polomi, Hlubočce, Podvihova, Jakubčovic, Skřipova, Budišovic se souhlasem okresního národního výboru v Bílovci požadovaly nejen prodloužení trati z Kyjovic-Budišovic aspoň do Pusté Polomi, jak bylo plánováno již před první světovou válkou, ${ }^{19}$ ale především její ponechání Společnosti moravských místních drah. Zdůvodňovaly své požadavky nejen pracovní silou pro Ostravu, ale také rozšířením jejího atrakčního území na úkor Opavy, zlepšením odbytových, resp. zásobovacích možností, ale i zdůrazněním rekreačního potenciálu této oblasti. Svou roli sehrávala také skutečnost, že obce předpokládaly, že právě vlastnictví této dráhy stávajícím majitelem, tedy Společností moravských místních drah, je klíčovou podmínkou pro její elektrizaci a prodloužení. ${ }^{20}$

Částečné řešení přinesla až porada všech zainteresovaných orgánů dne 13. března 1946 v Ostravě. ${ }^{21}$ Bylo konstatováno, že dráha do Kyjovic-Budišovic má být uznána jako majetek Společnosti moravských místních drah a že pro posouzení dalších otázek spojených s úzkorozchodnými drahami bude zř́zena komise se zástupci příslušných orgánů. Otázka vlastnictví výše uvedené dráhy, jakož i tratí do Hrušova a Michálkovic se však i nadále vlekla a ukončil ji až vznik komunálního dopravního podniku v roce 1949.

15 Tamtéž, zápis z 25. 1. 1946. Výměr odkazoval na ustanovení $§ 7$ odst. I. dekretu prezidenta republiky ze dne 19. 5. 1945 č. 5, podle něhož byla smlouva prohlášena za neplatnou a současně dle článku 6 odst. I, bodu o nastavení dekretu prezidenta republiky ze dne 3. 8. 1945 č. 11 úředního věstníku, zrušena. AMO, fond ÚNV, inv. inv. č. 5 , sign. XXII, kart. 1, uznání tržní smlouvy dne 24. 8.1946.

16 AMO, fond SMMD, inv. č. 33, zápis z 30.10.1945.

17 Jednalo se o akciový podnik se správní radou, která byla v době okupace obsazena převážně osobami s německým občanstvím. V čele správní rady stál vrchní komisař a později vrchní starosta Ostravy Emil Beier. Kjeho osobě např. PRZYBYLOVÁ, Blažena - ŠERKA, Josef: Muži s mocí : Portréty představitelu města Ostravy 1918-1989. Šenov u Ostravy 1999, s. 32-34.

18 Karel Garba uvádí, že za dráhu do Hrušova a Michálkovic společnost zaplatila celkem 3080000 K. K tomu je však potřeba připočíst i poplatky berní správě ve výši $215600 \mathrm{~K}$. Za dráhu do Kyjovic-Budišovic pak společnost uhradila $3012942,50 \mathrm{~K}$ včetně poplatků za převod. AMO, fond SMMD, inv. č. 27, zápis z 2. 4. 1946; tamtéž, inv. č. 33, zápis z 14. a 16. 7. 1945; GARBA, K.: Úzkorozchodné dráhy, I, s. 123.

19 K projektům v prostoru Opava, Hradec nad Moravicí, Polom a Skřípov viz např. POPELKA, Petr: Zrod moderní dopravy : Modernizace dopravní infrastruktury v Rakouském Slezsku do vypuknutí první světové války. Ostrava 2013, s. 207-210; HINČICA, Libor: Tramvají z Ostravy do Opavy. Československý dopravák. Doprava - technika - urbanismus 21. 10. 2018. Online, cit. 30. 5. 2020, http://www.cs-dopravak.cz/zpravy/2018/10/21/tramvaj-z-ostravy-do-opavy.

20 AMO, fond ÚNV, inv. č. 5, sign. XXII, kart. 1; Tamtéž, fond SMMD, inv. č. 33, zápis ze 4. 12. 1946; Tamtéž, inv. č. 27, zápis z 2. 4. 1946.

21 Porady se zúčastnili zástupci ministerstva dopravy, Moravskoslezského zemského národního výboru v Brně i jeho expozitury v Moravské Ostravě, národního výboru města i závodních rad jak Společnosti moravských místních drah, tak Slezských zemských drah, dále zástupce krajské rady odborů. AMO, fond SMMD, inv. č. 27, zápis z 2.4. 1946 . 


\section{Vznik komunálního dopravního podniku Ostrava}

\section{Společnost moravských místních drah}

K pochopení toho,jak komunální podnik vznikl a jaké na sebe převzal povinnosti,je potřeba věnovat pozornost nejen podobě správní rady společnosti, ale také obecnému správnímu a právnímu uspořádání poválečného Československa. Dosavadní literatura sice zohledňuje znárodnění či konfiskace velkých podniků či likvidaci živnostenského podnikání, ${ }^{22}$ otázka procesu vzniku komunálních podniků však stojí poněkud stranou tohoto zájmu. ${ }^{23}$ Svou roli může sehrávat skutečnost, že řada příslušných dokumentů je uložena v dosud nepřístupných fondech. Na základě dostupných údajů se následující ŕádky pokusí rekonstruovat vznik ostravského dopravního komunálního podniku, který vznikl v roce 1949 sloučením doposud samostatných dopravních podniků. ${ }^{24}$ Ve dvou z nich sehrávala zásadní roli městská, později lidová správa Ostravy. Dopravní společnost Místní dráha Moravská Ostrava - Karviná byla od svého založení v roce 1909 výhradně městským podnikem, ve Společnosti moravských místních drah pak bylo město Moravská Ostrava, resp. Ostrava majoritním akcionářem. ${ }^{25}$ Zatímco v případě první společnosti byl výkonný výbor obsazen od počátku představiteli městské samosprávy a po roce 1945 národního výboru, v případě Společnosti moravských místních drah byla situace komplikovanější tím, že podnik byl veden jako akciový, měl tedy ze zákona vyplývající povinnosti a vlastní organizace a fungování podniku bylo vázáno stanovami společnosti z roku 1921. ${ }^{26}$

Jak bylo již uvedeno, ke změnám se přistoupilo hned po skončení války a do správní rady byli delegování zástupci tehdejšího místního národního výboru. Celková obměna správní rady však proběhla již na mimořádné valné hromadě dne 16. července 1945 . Podle dekretu prezidenta republiky č. 5 z 19. května 1945 zaniklo členství německým členům správní rady i revizního výboru, čímž se správní rada stala usnášení neschopnou. Nakonec se tedy valná hromada rozhodla odvolat i zbylé členy správní rady Bohumila Rolka, Františka Poláška a Jana Geislera a oba orgány kompletně zvolit znovu.

Odvolání správní rady však bylo krokem nestandardním bez opory ve stanovách společnosti. Článek 15 těchto stanov totiž výslovně uváděl, že při trvalém zaneprázdnění,

22 Například KUKLÍK, Jan ml.: Znárodněné Československo. Praha 2010; TÝŽ: Dějiny československého práva 1945-1989. Praha 2011; KAPLAN, Karel: Znárodnění a socialismus. Praha 1968; DUFEK, Pavel: Vliv právního prostřední na soukromé podnikání v Československu v 50. a 60. letech 20. století. Acta Oeconomica Pragensia 13, 2005, č. 3, s. 163-189.

23 PALEČKOVÁ, Drahomíra - STEIN, Štěpán: Komunální podniky : Jejich ř́zení, organizace a provoz. Př́ručky pro národní výbory, 19. Praha 1949; ČERMIN, Jan: Socializace pohostinských živností v Brně v letech 1948-1953: Sonda do dějin komunálního podniku Pohostinské podniky města Brna. Bakalářská diplomová práce, Filozofická fakulta Masarykovy univerzity. Brno 2013; BUŠTOVÁ, Iva: Likvidace soukromého sektoru, drobných a středních živnostníků v Československu v letech 1948-1953. Diplomová práce, Fakulta humanitních studií Univerzity Karlovy. Praha 2019. K problematice na území Ostravy se vztahuje studie L. Cimalové, která je však zaměřena primárně na tzv. socializaci živností a obsahuje spíše sumární přehledy. Viz CIMALOVÁ, Libuše: Socializace obchodů, řemesel a jiných živností v Ostravě v letech 1949-1953. In: JIŘÍK, K. a kol.: Ostrava socialistická, s. 409-438.

24 Slučované podniky bývají uváděny různě v závislosti na tom, jak je chápána pozice bohumínských městských drah a autobusové dopravy.

25 K tomu nejnověji ZÁVODNÁ, Michaela: Město a koleje : Problematika městské kolejové dopravy ve vybraných moravských a slezských městech v letech 1850-1918. České Budějovice - Ostrava 2016.

26 Stanovy Společnosti moravských místních drah. Ostrava 1921. Dále Dodatek I ke stanovám Společnosti moravských místních drah. Ostrava 1923; Dodatek II. ke stanovám Společnosti moravských místních drah. Ostrava 1930. AMO, fond SMMD, inv. č. 170, kart. 1. Během okupace došlo pouze k drobným korekcím stanov s ohledem na změnu státní formy a němčinu jako úřední řeč. Tamtéž, inv. č. 13, Zápisy ze zasedání valných hromad 1945-1949, mimořádná valná hromada 16. 7.1945. 
úmrtí nebo výstupu některého člena správní rady před uplynutím jeho funkční doby může jeho místo být obsazeno správní radou provizorně do př́šstí valné hromady, která provede definitivní náhradní volbu. ${ }^{27}$ Člen správní rady se tedy o své vưli musel rozhodnout na místo rezignovat. $V$ prípadě, že počet členů klesl pod 12 , byla správní rada povinna uvolněná místa provizorně obsadit. Následující valná hromada akcionáŕů pak bud' tuto volbu potvrdila, nebo zrušila. ${ }^{28}$ Situace však byla komplikována také tím, že dle stanov mělo končit členům správní rady tříčlenné funkční období schválením roční bilance k poslednímu roku jejich mandátu. Jinak řečeno, členové správní rady, kteří byli odvoláni, v roce 1945 končili svůj mandát a měli rovněž schválit roční bilanci za rok 1945. Ve skutečnosti se však poslední valnou hromadou schválená výroční zpráva a bilance týkala roku $1941 .{ }^{29}$

Po odvolání zbylých členů správní rady přistoupila valná hromada akcionářù, tedy zástupci ostravského Národního výboru k volbě nových správních členů podle usnesení Národního výboru. Bylo zvoleno 12 správních radů v čele s Josefem Kotasem ${ }^{30}$ a následovala diskuse o úpravě stanov, které byly za protektorátu změněny. Tento krok byl vesměs kosmetický, odstraněny byly zmínky o protektorátu a protektorátní správě, povinnost německého občanství apod. Návrh Františka Rokovanského vyhradit polovinu míst ve správní radě závodnímu výboru vzbudil diskusi a následně byl navrhovatelem stažen z jednání. Ředitelem firmy zůstal ing. Viktor Fiala, rovněž pověřený její prokurou.

Na 58. řádné valné hromadě 28. prosince 1945 byla předložena ke schválení výroční zpráva a roční bilance společnosti za roky 1942 a 1943. V souladu se stanovami ${ }^{31}$ proběhla až 59. řádná valná hromada dne 2. dubna 1946, která schválila výroční zprávu společnosti za rok 1944 a změny ve složení správní rady, jižz i nadále předsedal Josef Kotas. ${ }^{32}$

Situaci ve správní radě však výrazně ovlivnil vývoj politické situace po roce 1946, v němž lze stále výrazněji sledovat odklon od demokratických a právních základů, na nichž byla (nejen) dopravní společnost založena. Odvolávání členů správní rady dle aktuálních potřeb závodního výboru ${ }^{33}$ či politické situace se stalo běžnou praxí. Stále zjevnější byla

\footnotetext{
27 Stanovy společnosti 1921, s. 11.

28 Tamtéž, s. 10.

29 AMO, fond SMMD, inv. č. 376, Jahresbericht des Verwaltungsrates des Mährischen Lokal-Eisenbahn-Gesellschaft für das Jahr 1941. Erstattet in der 57. ordentlichen Vollversammlung der Aktionäre am 9. Juni 1942. Mähr. Ostrau 1942.
}

30 Zaneseni do obchodního rejstř́ku dne 1. 10. 1945. Proběhl výmaz osob ing. Richard Proksch, Emil Beier, ing. Vilém Januschke, Gustav Pietsch, Richard Bartaschek, Alois Quitt, Viktor Schiffner, František Geschwinder, František Polášek, Jan Geisler, Bohumil Rolek a odvolána prokura Karla Beny a Albrechta Bräckera. Nově byli zapsáni Bohumil Rolek, finanční referent a současně člen bývalé správní rady, dále Antonín Vavroš, učitel ve výslužbě, který byl členem správní rady za protektorátu, Rudolf Hanke, Leopold Janíček, ing. Bohumil Krýsa, Roman Sýkorský, Oldřich Svozil a Jan Ševčík, za závodní výbor Rudolf Kucharský a František Rokovský. AMO, fond SMMD, inv. č. 13, zápis z 16. 7. 1945.

31 Dle článku 34 stanov měla řádná valná hromada povinnost scházet se v prvních šesti měsících správního roku. Stanovy společnosti 1921, s. 16.

32 Nutno bylo např. nahradit zemřelého ing. Krýsu ing. Antonínem Boušou a provést změny zástupců závodního výboru. Správní rada pak fungovala ve složení Josef Kotas (KSČ), Karel Sochorek, Rudolf Hanke (oba sociální demokrati), Antonín Vavroš, Bohumil Rolek, Leopold Janíček, Oldřich Svozil (všichni tři lidovci), ing. Antonín Bouša, Roman Sýkorský a Jan Ševčík, za závodní výbor František Lesničák (Lesniczak) a Karel Sebera. Původní členy Rokovanského a Kucharského závodní výbor odvolal. AMO, fond SMMD, inv. č. 13, zápis z valné hromady 20. 12.1945 .

33 Z politických důvodů byl na valné hromadě 2. 4. 1946 odvolán svou politickou stranou Roman Sýkorský. Nahrazen byl opět Františkem Rokovským. AMO, fond SMMD, inv. č. 27, zápis z 2. 4. 1946. 
snaha komunistů v Ústředním národním výboru ${ }^{34}$ posílit svou pozici ve správní radě společnosti na úkor zástupců ostatních politických stran sdružených v Národní frontě. V lednu 1947 adresoval Ústřední národní výbor vedení Společnosti moravských místních drah dopis, v němž uváděl seznam osob, které lidová správa vybrala jako své reprezentanty do správní rady společnosti, v níž měla Ostrava majoritní podíl. Jednalo se o sedm osob, z nichž pět bylo členy KSČ ${ }^{35}$ a dvě reprezentovaly národní socialisty. ${ }^{36}$ Dodatečně své zástupce navrhli sociální demokraté a lidovci. ${ }^{37}$ Dne 3. ledna 1947 tak vedení společnosti disponovalo seznamem, na základě něhož mělo dojít ke změnám ve správní radě. Jak upozornil v předchozí korespondenci ředitel dopravního podniku jak ing. Fiala, tak ústřední ředitel městských podniků ing. Adolf Eliášek, změny ve správní radě podléhaly schválení valnou hromadou. ${ }^{38} \mathrm{~V}$ rámci mimořádné valné hromady, která se konala tentýž den, tj. 3. ledna 1947, se tak změny správní rady neprojednávaly. Na pořadu dne bylo zásadní rozhodnutí o další existenci společnosti. Josef Kotas coby předseda správní rady i předseda Ústředního národního výboru informoval př́itomné o záměru města zreorganizovat veškerou dopravu do jednoho podniku, jehož provozovatelem bude město Ostrava. ${ }^{39}$ Cílem bylo nejen zjednodušit a zlevnit správu a provoz, ale především umožnit velkorysé rešení jednotlivých otázek dopravních, kteréžto úkoly dosud zastává rada podnikư. Cílem tedy byla likvidace společnosti tak, aby město Ostrava veškerou dopravu jakéhokoliv druhu, pokud je úkolem moderní veřejné správy, sloučila v jednom podniku s názvem „Dopravní podniky statutárního města Ostrava“ “. ${ }^{40}$ Právní forma měla být určena po dohodě př́slušných orgánů. $\mathrm{O}$ tomto návrhu valná hromada rozhodla kladně, firma se nově uváděla jako Společnost moravských místních drah v likvidaci a likvidátory byli jednomyslně zvoleni členové správní rady Josef Kotas, Karel Sochorek, Bohumil Rolek, Jan Ševčík a Antonín Vavroš. Od 14. ledna 1947 tak v řadě písemností dochází ke kolísání mezi označením výkonný výbor správní rady a likvidační komise. ${ }^{41}$

Rozhodujícím způsobem však do podoby správní rady zasáhly politické události roku 1948. Na žádost okresního akčního výboru Národní fronty byli v průběhu dubna a května odvoláni dosavadní dlouholetí členové správní rady, většinou mimo KSČ. S členstvím se tak rozloučili sociální demokraté Karel Sochorek a Rudolf Hanke, dále lidovci Bohumil Rolek, Leopold Janíček a Oldřich Svozil. ${ }^{42}$ Nadále mezi členy nefiguroval ani Antonín Vavroš.

\footnotetext{
34 Vyhláškou ministra vnitra č. 1903/1946 Úředního listu republiky Československé (dále Ú. l.) I došlo k přejmenování stávajícího Místního národního výboru na Ústř̌ední národní výbor. Viz JIŘíK, K.: Vývoj, s. 290.

35 Josef Kotas, Jaroslav Závodský - řidič u dopravní společnosti, Jan Balšínek, vrchní finanční komisař, Josef Olšovský, zř́zenec ČSD a František Zahel, mistr ve Vítkovických železárnách. AMO, fond SMMD, inv. č. 27.

36 Bohumil Pustka, úředník ČSD a Josef Váňa, tajemník Moravskoslezského zemského národního výboru. Tamtéž.

37 Za sociální demokraty měli být členy správní rady Karel Sochorek, Rudolf Hanke a dr. František Chmura, za lidovce Bohumil Rolek a Oldřich Svozil, ředitel gymnázia v Ostravě. Dopis správní radě z 2.1. 1947 jména členů sociální demokracie a lidovců neobsahuje, zápis správní rady z 3. 1. 1947 však již ano. Srov. AMO, fond SMMD, inv. č. 27 a 33, zápis z 3. 1. 1947.

38 Tamtéž, inv. č. 27.

39 Tato myšlenka není nijak nová. Vznik jednoho dopravního podniku, který by obstarával dopravu na Ostravsku, již za protektorátu prosazoval Emil Beier, který také inicioval zakoupení drah do Hrušova, Michálkovic a do Kyjovic-Budišovic. PRZYBYLOVÁ, B. - ŠERKA, J.: Muži, s. 32-34.

40 AMO, fond SMMD, inv. č. 13, zápis mimořádné valné hromady z 3.1. 1947.

41 Srov. Tamtéž, inv. č. 34, Zápisy schůzí likvidačního výboru 22. 7. 1948-7. 7. 1949, zápisy datované po 14. 1. 1947. Výkonný výbor tvořilo šest členů, které ze svého středu volila správní rada.

42 AMO, fond SMMD, inv. č. 27.
} 
Z 12 míst ve správní radě jich bylo osm vyhrazeno členům Ústředního národního výboru, resp. jeho rady s tím, že z těchto osmi osob pouze dvě patřily k jiné než komunistické straně. Zvýšil se rovněž počet zástupců závodního výboru. ${ }^{43}$ Ke schválení změn nadiktovaných akčním výborem Národní fronty, respektive Ústředním národním výborem došlo dne 28. dubna 1948 na mimořádné valné hromadě. Snaha obsadit správní radu „prověřenými kádry“ však byla nadbytečná. Podle článku 39 stanov totiž zvolením likvidátorů společnosti přestávala správní rada disponovat svými pravomocemi. Mnohem důležitější tedy bylo, že tato čistka se dotkla likvidátorů, kterými byli tři z odvolaných správních radů, konkrétně Vavroš, Sochorek a Rolek.

Noví likvidátoři z řad nově dosazených členů, jmenovitě Jaroslav Břustek, JUDr. Jan Balšínek a Josef Podešva, byli zvoleni na následující řádné valné hromadě akcionářů dne 22. května 1948.44 Optimistický předpoklad, že likvidace společnosti bude provedena do tři měsíců, ${ }^{45}$ se však nenaplnil také proto, že až v roce 1948 byla vyjasněna otázka daňových (dávkových) povinností firmy, která byla jednou z překážek faktické likvidace společnosti. ${ }^{46}$

Další změny přinesla po únoru 1948 také druhá vlna znárodnění, v níž se znárodnění zestátněním rozšířilo i na střední a malé podniky, obchod a živnosti, pro něž platilo, že kdykoliv od 1. ledna 1946 v nich pracovalo 50 a více zaměstnanců, avšak Společnosti moravských místních drah se tato druhá vlna znárodnění netýkala.

Pro oblast městské dopravy byl však zásadní zákon z 21. července 1948 č. 199/1948 Sb., o komunálních podnicích, v němž bylo upřesněno, že komunální podniky jsou národním majetkem v rukou svazků lidové samosprávy podle $§ 149$, odst. 2 ústavního zákona ${ }^{47}$ a může se jednat o podniky zř́zené z podnikového majetku svazků lidové samosprávy, konfiskovaného majetku či majetku smíšených společností. Rozhodující pravomoci o tom, co do komunálního podniku začleněno být má, či nemá, však připadly ministerstvu financí, vnitra a v tomto př́padě ministerstvu dopravy. ${ }^{48}$ Vznik a organizaci komunálního podniku rozvádělo poté vládní nařízení č. 10 z 18 . ledna $1949 .{ }^{49}$ Toto vládní nařízení umožňovalo zřídit tzv. sdružený komunální podnik, do něhož bylo možné spojit závody s podobným předmětem podnikání. Základem zamýšleného komunálního podniku města měl být majetek Společnosti moravských místních drah, který byl převeden na město usnesením likvidační komise z 22. záŕí 1948, resp. usnesením rady Ústředního národního výboru z 26. září 1948 a tímto usnesením také sloučen s majetkem

\footnotetext{
43 Tamtéž.

44 Tamtéž, fond SMMD, inv. č. 13, zápis z 60. řádné valné hromady 22. 5. 1948.

45 Tamtéž.
}

46 Teprve 8. 4. 1948 byl společnosti doručen výnos ministerstva financí č. 63.888/48-V/4 ze dne 22. 3. 1948. V tomto výnosu informovalo ministerstvo financí společnost o tom, že je vládou osvobozena od dávky z majetku a dávky z majetkového prŕrůstku. Současně také byly doměřeny daňové povinnosti za předchozí roky, bylo tedy možné schválit roční bilance. AMO, fond SMMD, inv. č. 189, kart. 7, dopis ministerstvu dopravy z 6. 10. 1948; Tamtéž, inv. č. 376, Výroční zpráva Společnosti moravských místních drah za rok 1945 daná na 60. řádné valné hromadě akcionář̉u dne 22. 5. 1948. Ostrava 1948.

47 Zákon č.150/1948 Sb. Ústavní zákon ze dne 9. května 1948. Ústava Československé republiky. Online, cit. dne 20.5. 2020, https://www.epravo.cz/vyhledavani-aspi/?Id=17433\&Section=1\&IdPara=1\&ParaC=2.

48 Zákon č. 199/1948 Sb. Zákon ze dne 21. července 1948 o komunálních podnicích. S výkladem PALEČKOVÁ, D. - STEIN, Š.: Komunální podniky, s. 19-88.

49 Nařízení vlády č. 10/1949 Sb. Vládní nařízení, kterým se provádí zákon o komunálních podnicích a vydává jejich statut (statut komunálních podniků). Online, cit. dne 20. 5. 2020, https://www.zakonyprolidi.cz/cs/194910. S výkladem PALEČKOVÁ, D. - STEIN, Š.: Komunální podniky, s. 89-164. 
místní dráhy z Moravské Ostravy do Karviné. ${ }^{50}$ Předpokládalo se, že do vznikajícího komunálního podniku budou zapojeny rovněž konfiskáty a znárodněné i neznárodněné soukromé živnosti z oblasti autoopravy a autodopravy.

Rada Ústředního národního výboru na svém zasedání dne 7 . března 1949 rozhodla o vzniku firmy s oficiálním názvem Dopravní podnik města Ostravy, komunální podnik sdruženýv Ostravě k datu 1. ledna 1949. Prozatímním správcem byl určen Jaroslav Břustek a podnik měl oficiálně zahájit svou činnost k 1 . březnu 1949. Zatímco usnesení spolu se zakládací listinou procházelo schvalováním dalších stupňů lidové správy, ${ }^{51}$ proběhla dne 26. března 1949 61. řádná valná hromada akcionářů a teprve na následující řádné valné hromadě dne 7. července 1949 bylo rozhodnuto o likvidaci společnosti a bezúplatném předání její majetkové podstaty Ústřednímu národnímu výboru v souladu s $§ 11$ vládního nařízení č. 10/1949 Sb. ${ }^{52}$

Snahy Ústředního národního výboru s cílem vybudovat jednotný dopravní komunální podnik se v průběhu roku 1948 a 1949 výrazně zkomplikovaly. V rovině zákonodárné sehrál úlohu zákon ze dne 22. prosince 1948 č. 311/1948 Sb., o národních dopravních podnicích. S účinností od 30. prosince 1948 znárodňoval zestátněním nestátní dráhy pro veřejnou dopravu, podniky pro pravidelnou silniční motorovou dopravu osob a nákladů, podniky pro pravidelnou leteckou dopravu a dále podniky konkrétních společností. Takto získaný majetek se stal kmenovým jměním nově vzniklých národních/státních podniků, např́íklad Československých drah (ČSD) či Československé automobilové dopravy (ČSAD).$^{53}$ Znárodnění zestátněním se nemělo týkat dopravních podniků, které byly od 1. prosince 1948 ve vlastnictví nebo správě (národní správě) svazků lidové správy nebo na nichž byly svazky lidové správy majetkově zúčastněny aspoň polovinou. V prrípadě podniků takto postižených, tj. těch, které byly znárodněny a současně náležely akciovým společnostem nebo společnostem s ručením omezeným, měly tyto společnosti zaniknout bez likvidace datem určeným ministerstvem dopravy. Seznam podniků podléhajících znárodnění měl být předmětem následných vyhlášek ministerstva, resp. ministra dopravy. ${ }^{54}$

Z výše uvedených důvodů tedy Společnost moravských místních drah, v níž majoritní podíl ve výši 97,3 \% drželo město Ostrava, a která byla od roku 1947 v likvidaci, znárodnění nepodléhala, a proto také není uvedena ve vyhlášce ministra dopravy ze dne 7. března 1949 č. 338/1949 Úředního listu (Ú. l.) II, č. 65 o znárodnění některých nestátních drah pro veřejnou dopravu. ${ }^{55}$

Problém však nastal s autobusovou dopravou, která byla integrální součástí této dopravní společnosti. Vyhláška téhož ministra ze dne 15. února 1949 č. 257 Ú. l. II,

\footnotetext{
50 AMO, fond SMMD, inv. č. 189 , kart. 7.

51 Plenární schůze Ústředního národního výboru schválila usnesení rady 28. 4. 1949, následně bylo předloženo Krajskému národnímu výboru a zakládací listina ministerstvu vnitra. Krajský národní výbor však zakládací listinu neschválil. AMO, fond JNV, inv. č. 5, zápis ze 4. řádné plenární schůze 27. 2. 1950; AMO, fond ŘMKP, inv. č. 38, sign. 1-244, kart. 22.
}

52 AMO, fond SMMD, inv. č. 34, zápis ze 7.7.1949; tamtéž, inv. č. 13, zápis ze 7.7.1949.

53 Doplnění slova „státní“ do názvů podniků bylo provedeno až zákonem č. 148/1950 Sb., čl. 1, odst. 1. 148. zákon ze dne 25. ř́jna 1950, kterým se mění a doplňuje zákon o národních dopravních podnicích. Online, cit. dne 30. 8. 2020, https://www.zakonyprolidi.cz/cs/1950-148.

54 Zákon č. 311/1948 Sb. Zákon z 22. prosince 1948 o národních dopravních podnicích. Online, cit. 20. 5. 2020, https://www.epravo.cz/vyhledavani-aspi/?Id=18276\&Section=1\&IdPara=1\&ParaC=2.

55 Vyhláška č. 338/1949 Ú. 1. II, č. 65. Vyhláška ministra dopravy ze dne 7. 3. 1949 o znárodnění některých nestátních drah pro veřejnou dopravu. Online, cit. 30.5.2020, https://www.epravo.cz/vyhledavani-aspi/?Id=21861 $\&$ Section=1\&IdPara=1\&ParaC $=2$. 
č. 55 o znárodnění některých podniků pro pravidelnou silniční motorovou dopravu osob a nákladů vyhlásila s účinností dnem doručení od 30. prosince 1948 znárodnění zestátněním pravidelné silniční autobusové dopravy osob a nákladů Společnosti moravských místních drah. ${ }^{56}$

Ústřední národní výbor však předpokládal, že součástí komunálního podniku bude také autobusová a nákladní doprava, o níž se domníval, že z hlediska místní dopravy patří dle zákona č. 199/1948 Sb. výlučně do provozu komunálních podniků. Proti citované vyhlášce se tak národní výbor ohradil a odkazem na odstavec 2 , § 1 zákona č. 311/1948 Sb. argumentoval, že majetková podstata neměla být znárodněna. ${ }^{57}$ Následně požadoval vyloučení podniku ze znárodnění ${ }^{58} \mathrm{~s}$ tím, že 62 . řádná valná hromada této společnosti rozhodla dne 7 . července 1949 o bezúplatném převodu svého majetku komunálním podnikům, i s odkazem, že komunální podniky jsou zproštěny povinnosti poskytnout Fondu znárodněného majetku hospodářskou náhradu za znárodněný majetek přenechaný jim do 31. prosince 1949. ${ }^{59}$ Nakonec se tedy Jednotný národní výbor rozhodl žádat ministerstvo dopravy o kroky vedoucí k přenechání znárodněných podniků svazkům lidové správy dle § 2 zákona č. 311/1948 Sb. a § 4 zákona č. 199/1948 Sb. ${ }^{60}$

V tomto duchu se nesl také výměr o rozsahu znárodnění podniku Společnosti moravských místních drah, který dne 22. května 1950 zaslalo ministerstvo vnitra Jednotnému národnímu výboru. $\mathrm{V}$ něm uvedlo, že vlastnictvím znárodněného podniku dne 30. 12. 1948 byly a spolu s ním podléhají znárodnění autobusy s tím, že výměr je konečný. ${ }^{61}$

Nejasnosti o rozsahu znárodnění však panovaly i nadále. Svědčí o tom korespondence mezi ministerstvem vnitra a Jednotným národním výborem. Jejím předmětem se stala otázka vyvlastnění zbývajících 1477 kusů akcií po $200 \mathrm{~K}$ na doručitele, protože u tohoto typu akcií byl držitel fakticky nezjistitelný. Dopravní komunální podnik ve svém dopisu z 1. prosince 1949 navrhoval zahájit vyvlastnění zbývajících akcií dle zákona ze dne 29. března 1935 č. 63/1935 Sb., o vyvlastnění k účelům obrany státu s tím, že je ochoten složit přiměřenou jistinu ve výši 295000 Kčs. ${ }^{62}$ Sekretariát společného představenstva komunálních podniků města Ostravy, který byl nadřízeným orgánem dopravního komunálního podniku, ${ }^{63}$ navrhoval Jednotnému národnímu výboru zahájit vyvlastnění dle $§ 3$

\footnotetext{
56 Vyhláška č. 257/1949 Ú. 1. II, č. 55. Vyhláška ministra dopravy ze dne 15. 2. 1949 o znárodnění některých podniků pro pravidelnou silniční motorovou dopravu osob a nákladu. Online, cit. 30.5. 2020, https://www.epravo.cz/ vyhledavani-aspi/?Id=21707\&Section=1\&IdPara=1\&ParaC=2.

57 AMO, fond ŘMKP, inv. č. 87, sign. 1-23, kart. 22.

58 Ačkoliv bylo zákonem č. 311/1949 Sb. v odd. 5 umožněno ministrovi vyjmout podnik ze znárodnění, ústavní zákon č. 150/1945 Sb. toto v § 153, odd. 3 neumožňoval, nebot uváděl, že zákonem vymezený rozsah provedeného znárodnění nemůže být omezen. Ministr tedy mohl rozhodnout o tom, že podnik do znárodnění zařazen nebude. Pokud však byl podnik v zákoně uveden, již z něj nemohl být vyjmut a muselo se přistoupit k aplikaci jiných zákonných norem.
}

59 AMO, fond JNV, inv. č. 1173, kart. 596; tamtéž, fond ŘMKP, inv. č. 87, sign. 1-23, kart. 22.

60 Tamtéž.

61 AMO, fond JNV, inv. č. 1173, kart. 596, dopis z 22. 5. 1950. O přenechání za náhradu rovněž hovořil § 2 zákona č. 311/1948 Sb.

62 Zákon č. 199/1948 Sb., § 3, bod 8, výklad PALEČKOVÁ, D. - STEIN, Š.: Komunální podniky, s. 24-25; AMO, fond JNV, inv. č. 1173 , kart. 596.

63 Libuše Cimalová vymezuje na základě archivních zdrojů roli sekretariátu takto: Spolu s vyhlášením komunálních podniků schválilo plénum ÚNV na zasedání dne 24. 3. 1949 jednotné organizační schéma všech komunálních podniků a pro jejich správu zř́dilo Společné představenstvo a jeho sekretariát. Společné predstavenstvo vedlo jménem ÚNV správu všech komunálních podniků města Ostravy a rozhodovalo o všech záležitostech, které nebyly zákonem 
zákona č. 199/1948 Sb. ${ }^{64}$ Jednotný národní výbor se v této záležitosti dotázal ministerstva vnitra a jeho odpověd' z 27. prosince 1949 situaci nezpřehlednila. Ministerstvo vnitra totiž uvedlo, že vyvlastňovací řízení není třeba provádět, protože dráha Společnosti moravských místních drah byla znárodněna celá. Tento výklad však Sekretariát společného představenstva komunálních podniků města Ostravy odmítl s poukazem na vyhlášku ministerstva dopravy č. 2482 z 30. listopadu 1949, kterým se do dopravního komunálního podniku začleňovala pouze pravidelná silniční motorová doprava. ${ }^{65}$

Dopravní podnik však i přesto požádal, aby byla ponechána původní žádost v platnosti a za pravdu mu nakonec dal i dopis ministerstva vnitra z 11. ledna 1950, v němž se, v jiné souvislosti, hovoří o tom, že znárodnění se týkalo pouze silniční motorové dopravy. ${ }^{66}$ Definitivní rozřešení celé situace kolem vyvlastňování akcií se nicméně v pramenech bohužel prozatím rekonstruovat nepodařilo. ${ }^{67}$

Ústřední, později Jednotný národní výbor se pokoušel do komunálního dopravního podniku začlenit také meziměstskou autobusovou dopravu a nákladní dopravu, a to opět s odkazem na zákon č. 199/1948 Sb. Zde však narazil na nesouhlas ministerstva dopravy s tím, že veškerá nákladní doprava má být svěřena výhradně národnímu podniku ČSAD. ${ }^{6}$ Ministerstvo vnitra, jehož souhlasu byl rovněž potřeba, naopak prosazovalo společně s Dopravní skupinou dráhy při Ústředním svazu dopravy v Praze ${ }^{69}$ individuální posouzení každého dopravního komunálního podniku. Ústřední národní výbor se ztotožnil s názorem ministerstva vnitra a vyzval vedení Společnosti moravských místních drah k dodání konkrétních argumentů, které by toto stanovisko podpořily. Dne 11. dubna 1949 poté Ústřední národní výbor zaslal na ministerstvo vnitra svůj pohled na věc. Místo konkrétních argumentů se však jednalo o poněkud vágní konstatování místních potřeb s odvoláním na prostorovou delimitaci budov státní správy a potřebu vlastní nákladní dopravy, která mohla sloužit i k dopravě soukromé, tedy po živnostensku provozované.

Výsledkem této aktivity byl dopis ministerstva vnitra ze 4. srpna 1949, v němž nyní již Jednotnému národnímu výboru oznámil, že ministerstvo dopravy souhlasí s tím, aby podnik provozoval pravidelnou i nepravidelnou veřejnou dopravu osob v oblasti katastrálního území obce Ostrava a v zastavěných částech sousedících obcí, které tvoři s Ostravou jeden hospodářský celek. Avšak provozování pravidelné dopravy osob mimo tuto zájmovou oblast nepřichází $v$ úvahu. ${ }^{70}$ Ministerstvo dopravy tímto tedy také odmítlo začlenit do komunálního podniku znárodněné živnosti autodopravců, kteří se soustředili na

prímo podř́zeny usnesením NV. Předsedou byl jmenován hospodářský referent ÚNV Miroslav Šodek, místopredsedou Josef Kotas, členy dr. Jan Balšínek a Vladimír Kozok. Sekretariát predstavenstva pracoval jako výkonný orgán, ř́dil, koordinoval, plánoval a kontroloval veškerou činnost komunálních podniků a jejich jménem jednal súrady, národními podniky aj. Vedoucím sekretariátu byl ustaven dr. J. Štýbar. CIMALOVÁ, Libuše: Sekretariát společného představenstva komunálních podniků města Ostravy, poté ředitelství. AMO, fond ŘMKP, inventář, s. 5.

64 AMO, fond ŘMKP, inv. č. 87, sign. 1-23, kart. 22.

65 Vyhláška ministra dopravy ze dne 30. listopadu 1949 č. 2482, Ú. l. II, částka 286.

66 AMO, fond ŘMKP, inv. č. 38, sign. 1-244, kart. 22.

67 Libuše Cimalová odkazuje na to, že již v průběhu prosince 1948 byla soukromá majetková účast ve výši 3 \% ve Společnosti moravských místních drah zlikvidována. Ve světle archiválií je však toto datum chybné. CIMALOVÁ, L.: Socializace, s. 418.

68 AMO, fond ŘMKP, inv. č. 38, sign. 1-244, kart. 22.

69 Tamtéž, fond SMMD, inv. č. 189, kart. 7. K historii, organizaci a práci Ústředního svazu viz ŠTEMBERK, Jan: Ústřední svaz dopravy 1940-1948. Acta Oeconomica Pragensia 15, 2007, č. 7, s. 405-416.

70 AMO, fond JNV, inv. č. 1173, kart. 596. 
meziměstskou autobusovou dopravu ${ }^{71}$ a které chtěl Jednotný národní výbor začlenit do dopravního komunálního podniku, a úpravu dopravy do rekreačních oblastí ponechalo primárně na domluvě mezi vznikajícím komunálním podnikem a ČSAD. ${ }^{72}$

\section{Slezské zemské dráhy}

Pro Slezské zemské dráhy bylo poválečné období poměrně turbulentní. Jak jsme již uvedli, před rokem 1949 probíhaly spory především se Společností moravských místních drah o vlastnictví tratí do Michálkovic, Hrušova a Kyjovic-Budišovic. Ačkoliv již v roce 1945 bylo provedeno tzv. opětovné pozemštění zemských drah výnosem ostravské expozitury Moravskoslezského zemského národního výboru, ${ }^{73}$ i nadále panovala mezi firmami značná nevraživost. ${ }^{74}$ Současně se Moravskoslezský zemský národní výbor začal zabývat otázkou dopravní obslužnosti Ostravska jako celku a s tím souvisejícím stavem bohumínské městské pouliční dráhy, která byla od listopadu 1946 z technických důvodů mimo provoz. Otázka koupě bohumínské dráhy a jejího začlenění do Slezských zemských drah se stala v letech 1946-1949 nedílnou součástí jednání Moravskoslezského zemského národního výboru o vlastnických poměrech dráhy do Kyjovic-Budišovic především z ekonomických důvodů. ${ }^{75}$ Moravskoslezský zemský národní výbor předpokládal, že kupní cenu ve výši 1861000 Kčs částečně uhradí z provozních příjmů bohumínské dráhy pro roky 1948 a 1949 a část ve výši 1561000 Kčs poté pokryje financemi z prodeje svinovsko-kyjovické dráhy Společnosti moravských místních drah. ${ }^{76}$ Situace se však začala komplikovat. Ukázalo se, že na bohumínské dráze váznou mnohem větší dluhy, než město původně přiznalo, ${ }^{77} \mathrm{v}$ případě dráhy do Kyjovic-Budišovic zase nebyla dořešena situace kolem kupní smlouvy dráhy do Michálkovic a Hrušova z roku 1943, která s ní úzce souvisela, ${ }^{78}$ v pozemkových a železničních knihách panoval nepořádek ohledně kyjovicko-budišovické dráhy, chyběly inventáře a předávací protokoly majetků firem z doby okupace. Prodej samotný také narážel na odpor některých členů Moravskoslezského zemského národního výboru, kteří odmítali předat zemský majetek soukromé firmě. ${ }^{79}$

71 Ústřední národní výbor žádal o začlenění devíti znárodněných dopravních firem, které původně provozovaly
autobusové linky v prostoru Horní Datyně, Staré Vsi nad Ondřejnicí, Staříče, Brušperka, Frýdku, Horní a Pro-
střední Bečvy, Trojanovic a Rožnova pod Radhoštěm. Ústřední národní výbor zdůvodňoval svoji žádost tím, že se
jedná o národohospodářský a provozní doplněk celkového dopravního plánu průmyslového Ostravska, do něhož
denně dojíždí množství dělníků. AMO, fond ŘMKP, inv. č. 87, sign. 1-23, kart. 22 . 72 ALBRECHT, Miroslav a kol.: Od omnibusu k elektrobusu : 85 let autobusové dopravy v Ostravě 1930-2015. Ostrava 2015, s. 16-20; AMO, fond SMMD, inv. č. 189, kart. 7, zápis z jednání dopravní skupiny dráhy z 24. 6. 1948 .

73 ZAO, fond MZNV, exp. O, inv. č. 804, kart. 829.

74 Firmy si posílaly prostřednictvím svých právních zástupců dopisy, v nichž se vzájemně osočovaly z neoprávněného držení části inventářů. Situace dospěla do bodu, kdy Společnost moravských místních drah trvala na vrácení pražců, které mělo ředitelství Slezských zemských drah zadržovat. Naopak ředitelství Slezských zemských drah trvalo na vrácení psacího stroje. ZAO, fond SZD Bohumín, inv. č. 411, kart. 109.

75 ZAO, fond MZNV, exp. O, inv. č. 226, kart. 78-79, zápisy ze zasedání Moravskoslezského zemského národního výboru v letech 1946-1948.

76 Nešlo primárně o prodej, ale o vyúčtování a odečet vzájemných závazků a pohledávek mezi zemí a akciovou společností vyplývajících z neplatnosti smluv o prodeji drah do Kyjovic-Budišovic, Michálkovic a Hrušova. Tamtéž.

77 Tamtéž, inv. č. 233, sign. pres., kart. 90, zápis ze 72. schůze rady MZNV, exp. O, konané dne 2. 7. 1948.

78 ZAO, fond SZD Bohumín, inv. č. 441, kart. 109.

79 Srovnej např. zápis ze zasedání MZNV ve dnech 24. a 25. dubna 1946, 4. zasedání, I. správní údobí a námitky lidovce Arnošta Kudělky, ZAO, fond MZNV, exp. O, inv. č. 226, kart. 78 nebo zápis ze 4. schůze téhož orgánu dne 
Situaci komplikovaly i úvahy o vzniku krajského komunálního dopravního podniku, který by zohlednil dopravní potřeby širšího Ostravska. ${ }^{80}$ Zatímco jeho zastáncem bylo především ředitelství Slezských zemských drah, ${ }^{81}$ proti se stavěli jak vedoucí představitelé Společnosti moravských místních drah v likvidaci, tak jejich zaměstnanci i Ústřední národní výbor. ${ }^{82}$ Poté, co bylo zřejmé, že ani ministerstvo dopravy prozatím nijak netrvá na tvorbě krajských komunálních podniků, ${ }^{83}$ se začaly v průběhu března 1949 ubírat úvahy Jednotného i Krajského národního výboru směrem k zapojení jmenovaných tratí do ostravského komunálního podniku. ${ }^{84}$ Důvodem bylo především ustanovení $§ 39$ zákona č. 280/1948 Sb., o krajském zřízení. K 31. prosinci 1948 totiž zanikly země Česká a Moravskoslezská jako svazky lidové správy a ministerstvo vnitra po dohodě s ministerstvem financí a příslušnými ministerstvy mělo převést jednotlivé části zůstatkové podstaty zásadně na svazky lidové správy. Tento převod se však měl dít teprve poté, co se k této otázce vyjádří Krajský národní výbor. ${ }^{85}$ V tomto prrípadě rada tohoto výboru v květnu 1949 doporučila ministerstvu vnitra, aby veškerý majetek Slezských zemských drah převedlo ze Země moravskoslezské na město Ostrava za účelem vytvoření komunálního podniku. Rovněž rada Krajského národního výboru informovala Jednotný národní výbor o tom, že velká část úseků zmiňovaných tratí se nachází v obvodu okresního národního výboru Karviná, který žádá o přizvání dvou zástupců do správy podniku. ${ }^{86}$ Jednotný národní výbor tuto žádost zamítl, avšak přislíbil přizvat zástupce okresního národního výboru na jednání s hlasem poradním.

Převod Slezských zemských drah na komunální podnik však nebyl jednoduchý, protože mezi zaniklou Zemí moravskoslezskou a bývalou Společností moravských místních drah existovaly dle ministerstva vnitra vzájemné za okupace vzniklé a dosud nevyřízené pohledávky.

Za dráhu Svinov - Kyjovice-Budišovice totiž měla dle ministerstva společnost zemi dlužit ještě sumu 1861000 Kčs, anulováním prodeje tratí do Hrušova a Michálkovic země naopak dlužila společnosti sumu 3080000 Kčs. Rozdíl 1219000 Kčs při účet-

19. 12. 1947, kdy byly návrhy prodeje kyjovické dráhy a koupě bohumínských drah zamítnuty. Tamtéž, inv. č. 226, kart. 79.

80 Poukazováno bylo především na skutečnost, že stávající společnosti, které by měly být začleněny do ostravského dopravního podniku, obsluhují mnohem větší území, než jen tzv. Velkou Ostravu, a proto by mělo dojít s ohledem na zákon č. 199/1948 Sb. ke vzniku krajského dopravního podniku. ZAO, fond Sm KNV Ostrava, sign. 152, kart. 2414.

81 ZAO, fond SZD Bohumín, inv. č. 69a, kart. 29. Ředitelství Slezských zemských drah se domnívalo, že spravuje dráhy meziměstského či okresního charakteru a že jeho připojením k ostravskému komunálnímu podniku dojde ke ztrátě všeobecného a nestranného zájmu na potrebách celé gravitační oblasti SZD a zvýšené uplatňování zájmů vlastního města na úkor jiných obcí gravitační oblasti, diktovaných lokálním patriotismem. Slezské zemské dráhy naopak navrhovaly, aby k nim byla přičleněna místní dráha Moravská Ostrava - Karviná i Společnost moravských místních drah. Jednoduše řečeno, Slezské zemské dráhy nechtěly přijít o své postavení samostatného podniku.

82 AMO, fond SMMD, inv. č. 189, kart. 7, dopis z 10. 2. 1949, 24. 3. 1949; Tamtéž, inv. č. 34, zápis z 26. 2. 1949. Informaci o úvahách o zřízení krajského dopravního podniku přinesl např. článek Krajský dopravní komunální podnik. Práce 12.2.1949, č. 36, s. 4.

83 ZAO, fond Sm KNV Ostrava, sign. 152, kart. 2414, zápis z porady na ministerstvu vnitra v Praze dne 5. 3. 1949 ohledně vytvoření krajského komunálního podniku elektrických drah.

84 Tamtéž.

85 Zákon č. 280/1948 Sb. Zákon z 21. prosince 1948 o krajském zřízení, § 39, bod 1-3; KUKLÍK, J. ml.: Dějiny, s. $190-195$.

86 AMO, fond JNV, inv. č. 1173, kart. 596, dopis z 3. 5. 1949; ZAO, fond Sm KNV Ostrava, sign. 152, kart. 2414. 
ním anulování těchto pohledávek však převod komplikoval, protože majetek bývalých Slezských zemských drah měl být převeden do komunálního podniku bez náhrady. Ministerstvo tedy žádalo dopravní společnost (sic!), aby se tohoto nároku vzdala. ${ }^{87}$ Že na tuto žádost město přistoupilo, svědčí převodní výměr z 16. 1istopadu 1949, kterým byl do komunálního podniku ke dni 1. ledna 1949 převeden veškerý movitý a nemovitý majetek Slezských zemských drah. ${ }^{88}$ Obdobný výměr pro bohumínskou elektrickou dráhu vč. vlečky následně Jednotný národní výbor obdržel 9. prosince $1949 .{ }^{89}$ Zpoždění bylo dáno tím, že majetek mohl být na komunální podnik převeden až poté, co proběhlo formální zaknihování vlastnického práva $\mathrm{k}$ tomuto majetku v pozemkových knihách na Zemi moravskoslezskou. ${ }^{90}$

\section{Majetková podstata dopravního podniku do roku 1950}

Všechny výše uvedené změny však výrazně zasáhly do podoby zakládací listiny komunálního podniku. Ačkoliv usnesením pléna Ústředního národního výboru ze dne 24. března 1949 byly dnem 1. března 1949 se zpětnou platností k 1. lednu 1949 vyhlášeny v Ostravě komunální podniky, tedy i Dopravní podnik města Ostravy, komunální podnik sdružený v Ostravě, původní zakládací listina schválená plénem Ústředního národního výboru dne 28. dubna 1949 nebyla předložena ke schválení Krajskému národnímu výboru. Dle této původní zakládací listiny měl podnik provozovat především pravidelnou hromadnou dopravu tramvajovou, trolejbusovou, autobusovou a vodní, dále se měl zabývat provozováním pravidelné hromadné dopravy rekreační, nepravidelné dopravy osob, provozováním dopravy nákladů, vagonového i kusového zboží a dalšími doprovodnými službami. ${ }^{91}$ Počítalo se především s majetkovými podstatami místní dráhy Moravská Ostrava - Karviná, dále s majetkovou podstatou Společnosti moravských místních drah a konfiskáty či znárodněnými místními zámečnickými, klempířskými a autoopravárenskými firmami. ${ }^{92}$

Je zřejmé, že turbulentní vývoj v letech 1949-1950, kdy panovaly nejasnosti ohledně předmětu podnikání a vůbec zřizování komunálních podniků, spory při vymezování zájmových dopravních oblastí či nevraživost mezi jednotlivými dopravními firmami,

\footnotetext{
87 Srov. AMO, fond SMMD, inv. č. 189, kart. 7; tamtéž, inv. č. 33, zápisy z 25. 1. 1946, 21. 5.1947 a 21. 1. 1948; tamtéž, inv. č. 34, zápisy z 22. 7. 1948 a 9. 10. 1948; ZAO, fond MZNV, exp. O, inv. č. 226, kart. 78-79, zápisy ze zasedání Moravskoslezského zemského národního výboru v letech 1946-1948.
}

88 AMO, fond JNV, inv. č. 1173, kart. 596, dopis z 28. 10. 1949. Podle protokolu sepsaného dne 13. 12.1949 u ústřední správy dopravních podniků města Ostravy byl na základě výměru převeden dnem 1. 1. 1949 na město Ostravu veškerý majetek bývalých Slezských zemských drah, tedy jak dráhy, tak nemovitosti, práva a povinnosti se zemským podnikem související. Dopravní podnik rovněž přebírá podpůrný fond zaměstnanců, zaměstnance, převádí na sebe koncese apod. ZAO, fond SZD Bohumín, inv. č. 350, kart. 110.

89 Tamtéž, dopis z 16.11. 1949.

90 Tamtéž, dopis z 18. 11. 1949.

91 Jednalo se především o: provoz a udržování garáží, dílny pro udržování a opravu motorových vozidel, vulkanizační dílny na opravu pneumatik, nákup a prodej olejů a pohonných hmot, nákup a prodej součástek v rámci služeb zákazníkovi, podporu cestovního ruchu a zcizování, kupování a pachtování podniků, zcizování a získávání nemovitostí, zakládání poboček a provozování všech vedlejších obchodů, kterážto činnost jest nutná k dosažení účelů shora uvedených. AMO, fond ŘMKP, inv. č. 87, sign. 1-23, kart. 22.

92 Jednalo se konfiskát firmy František Praschivka, zámečnictví Ostrava, dále o znárodněné firmy Richard Novák, klempíŕství Ostrava, František Riedel, autodílna Ostrava I, Rudolf Brenek, auto-moto-elektrodílna, Ostrava I. Tamtéž. 
výrazně zasáhly do podoby zakládací listiny, potažmo komunálního dopravního podniku. V praktické rovině bylo nezbytné vyřešit otázku znárodnění autobusové dopravy Společnosti moravských místních drah na jedné straně, na druhé straně akceptovat delimitaci autobusových linek mezi ČSAD a komunálním dopravním podnikem. Schvalování zakládací listiny pozdržela rovněž diskuse kolem zamýšlené vodní dopravy. V průběhu let 1949 a 1950 musel Jednotný národní výbor vysvětlit ministerstvu dopravy svou žádost o povolení provozovat lodní dopravu. Ministerstvo dopravy původně tuto žádost zamítlo s poukazem na skutečnost, že dopravu na Odře může provozovat pouze př́íslušný národní podnik a že v blízkosti Ostravy není žádná jiná vodní plocha. Ustoupilo teprve v okamžiku, kdy bylo upřesněno, že se jedná o rekreační dopravu na přehradách, které existují (Kružberk), nebo budou v budoucnu vybudovány (Hlučín, Žermanice), v rozsahu, vjakém ji provozují např́íklad dopravní podniky Brna na přehradě Kníničky či dopravní podniky Bratislavy. Do zakládací listiny ji však ministerstvo nechtělo nechat zahrnout. ${ }^{93}$

Další problémy se zakládací listinou dopravního podniku spočívaly, jak již bylo uvedeno, v otázce přenechání majetkové podstaty bývalé Země moravskoslezské, tedy bývalých Slezských zemských drah. Je zřejmé, že v průběhu schvalování zakládací listiny, a především předmětu podnikání komunálního podniku došlo k tak zásadním změnám, že bylo nakonec rozhodnuto usnesení plenární schůze Ústředního národního výboru z 28. dubna 1949 zrušit a nahradit ustanovením novým. ${ }^{94}$

Toto rozhodnutí rady Jednotného národního výboru z 10. února 1950 schválilo jak její plénum, tak Krajský národní výbor. Zř́izeny tedy byly Dopravní podniky města Ostravy, komunální podnik a současně byla schválena jeho zakládací listina, tvořená 10 články. V nich se uvádělo, že komunální podnik je majetkem národním, avšak v komunálním vlastnictví města Ostravy. Výrazných změn doznal článek 4, který vymezoval předmět podnikání. Formulace jednotlivých bodů byla obecnější, již se například nehovořilo o autobusové dopravě, ale o provozu pravidelné a nepravidelné hromadné dopravy osob a jejich cestovních zavazadel motorovými vozidly. Ve srovnání s obsahem předchozí zakládací listiny byla podniku povolena nákladní doprava pouze trolejbusy a pouliční drahou. Vyjmuta byla lodní doprava, předmět podnikání byl však nově rozšířen o nepravidelnou nehromadnou dopravu osob, tzn. o taxi. V článku 6 byl rovněž upřesněn rozsah majetkových podstat. Jádro firmy tvořila majetková podstata místní dráhy Moravská Ostrava - Karviná, dále Společnosti moravských místních drah v rozsahu usnesení likvidační valné hromady ze dne 7. července 1949 (dráhy, nemovitosti, parcely) a na základě vyhlášky ministra dopravy z 20. listopadu 1949 č. 2482, podle níž byla městu Ostrava přenechána majetková podstata této společnosti sloužící pravidelné silniční motorové přepravě a majetkové podstaty Slezských zemských drah na základě př́slušných převodních výměrů. Do majetkové podstaty komunálního dopravního podniku rovněž spadala nemovitost v knihovní vložce č. 704 katastrálního území Nový Bohumín s domem č. p. 686 jako konfiskát. Součástí majetkové podstaty zůstaly i konfiskáty a znárodněné živnosti v oblasti klempířství, zámečnictví a autoopravy. ${ }^{95}$ Zakládací listina

93 AMO, fond JNV, inv. č. 1173 , kart. 596.

94 Tamtéž, fond ŘMKP, inv. č. 87, sign. 1-23, kart. 22. Dopis Jednotného národního výboru ministerstvu dopravy z 8. 7. 1949. Předpokládalo se vydání zakládací listiny a její úpravy prostřednictvím dodatkování. Tamtéž, inv. č. 1 , kart. 1 .

95 Tamtéž, inv. č. 87, sign. 1-23, kart. 22. Z živností byly z majetkové podstaty k 1. 7. 1950 vyčleněny konfiskáty Brenek a Riedel, které přešly na nově utvořený komunální podnik Auto-Kovo-údržba. Ke stejnému datu byl nově do majetkové podstaty převeden z komunálního podniku Sdružené živnosti závod č. 4100, který sdružoval dva soukromníky (Jan Lysek, František Veselský) a 1 konfiskát (Jan Schmuck). 
komunálního podniku byla schválena radou Krajského národního výboru jako dohlédacího orgánu dne 30. června 1950. Komunální podnik byl vyhlášen v Ú. l. II. dílu, částka 181 dne 5. srpna 1950 a zapsán do podnikového rejstř́iku u okresního civilního soudu v Ostravě dnem 25. záŕí 1950, č. j. Firm 4372/50-A-XI-405/1. ${ }^{96} \mathrm{~V}$ čele komunálního podniku stanul coby správce Hynek Socha. ${ }^{97}$

\section{Závodní dráhy Vítkovických železáren Klementa Gottwalda - Komárek}

Dalším podnikem, o kterém se v rámci vytváření jednoho dopravního podniku v Ostravě jednalo, byla závodní dráha Vítkovických železáren do Zábřehu k pískovým dolům a do Hrabové, které se přezdívalo Komárek. Jednání byla obtížná a svou roli v nich zřejmě sehrávala i rivalita Vítkovických železáren a Společnosti moravských místních drah, která v dopravní oblasti sahala hluboko do minulosti. ${ }^{98}$ Průběžně spolu jednali zástupci Ústř̌edního, později Jednotného národního výboru, ředitel Společnosti moravských místních drah, ředitel závodní dráhy i ústřední ředitel Vítkovických železáren. Snaha inkorporovat Komárka do vznikajícího komunálního dopravního podniku nebyla vedena jen tarifními otázkami. ${ }^{99}$ Pro Společnost moravských místních drah, resp. vzniklý komunální podnik, byl zisk této trati do vlastní správy klíčový ze dvou důvodů. Tím prvním byla neudržitelná dopravní situace ve Vítkovicích, kde se úrovňově křižovaly tramvajové trati a závodní vlečky. Vyřešení dopravní situace $\mathrm{v}$ této oblasti představovalo zároveň podmínku dalšího rozvoje dopravní sítě směrem $\mathrm{k}$ Zábřehu, Výškovicím a Bělskému lesu. ${ }^{100}$

Ačkoliv obě strany byly zpočátku nakloněny technickému sloučení drah bez změny majetkových a vlastnických poměrů, $\mathrm{k}$ dohodě se nakonec nedospělo. ${ }^{101}$ Svou roli sehrála i skutečnost, že závodní dráha byla majetkem Vítkovických železáren a $z$ důvodů válečného průmyslového charakteru a pro di̊ležitost obrany státu [byla] vyjmuta z jednání a scelování dopravních podniků. ${ }^{102}$

V průběhu zdlouhavého vyjednávání bylo stále patrnější, že představitelé Jednotného národního výboru i dopravního podniku ztrácejí trpělivost se zástupci Vítkovických železáren, kteří jednání stále více obstruovali. Spíše než o zásadní technické problémy

\footnotetext{
96 Tamtéž, inv. č. 87, sign. 1-23, kart. 22; tamtéž, inv. č. 1, kart. 1.

97 Hynek Socha působil v pozici správce dopravního podniku do roku 1952. Poté byl odvolán a v tisku proti němu proběhla štvavá kampaň. Lze předpokládat, že byla úzce spojena s hledáním třídního neprítele, kterým by se ospravedlnily zásadní problémy v hospodářství, které neminuly ani oblast dopravy. Srov. životopis v AMO, fond JNV, inv. č. 1173, kart. 596; HLAVÁČOVÁ, Jožka: Bývalí sociálně demokratičtí pravičáci př́ččnou nepořádků v Dopravních podnicích. Nová svoboda 25. 5. 1952, s. 4 a 6; AMO, fond JNV, inv. č. 75, 4. schůze rady JNV 8.9. 1949.

98 K tomu např. KROČEK, Miloslav: Osudy projektu železniční trati Mariánské Hory - Brušperk - Kozlovice. In: JIŘíK, Karel (ed.): Ostrava. Př́spěvky k dějinám a současnosti Ostravy a Ostravska, 17. Šenov u Ostravy 1995, s. 195-222; FABIÁN, Radim: Výstavba trati Hrabová-Ostrava v kontextu vývoje meziválečné dopravní infrastruktury Ostravska. Bakalářská práce. Katedra historie. Filozofická fakulta. Ostravská univerzita 2018.

99 AMO, fond SMMD, inv. č. 189, kart. 7, pamětní zápis z 11. 11. 1946; Tamtéž, fond JNV, inv. č. 10, zápis z 8. rádné plenární schůze JNV 22. 2. 1951.

100 V Zábřehu probíhala výstavba tzv. vzorového sídliště. K tomu STRAKOŠ, Martin: Nová Ostrava a její satelity. Kapitoly z dějin architektury 30.-50. let 20. století. Ostrava 2010, s. 119-136; LIPTÁK, Marian - PŘENDÍK, PetrMAJLIŠ, Tomáš - SZTURC, Antonín: Městský obvod Ostrava-Jih včera a dnes. Ostrava 2017, s. 35, 42-43.

101 AMO, fond SMMD, inv. č. 189, kart. 7, pamětní zápis z 11.11. 1946 a dopravní porada z 6. 10.1947.

102 Tamtéž. Dne 31. 1. 1949 potvrdilo ministerstvo průmyslu výnosem č. j. 25012/49-VIII/5 nutnost zachovat dráhu v držení a provozu národního podniku Vítkovických železáren Klementa Gottwalda. Tamtéž, fond DPO, nezpracováno, kart. 132.
} 
šlo více méně o malichernosti, přičemž z jednání je patrné, že Vítkovické železárny se dopravních tratí, které sloužily primárně jejich zaměstnancům, vzdát nechtějí. ${ }^{103}$ Zásadně odlišná stanoviska však komplikovala velkolepé dopravní plány úzce svázané s výstavbou tzv. nové Ostravy i s rozvojem Nové huti Klementa Gottwalda a bylo jen otázkou času, kdy budou Vítkovické železárny Klementa Gottwalda donuceny souhlasit s požadavky orgánů lidové správy i dopravního komunálního podniku. ${ }^{104} \mathrm{~K}$ začlenění obou tratí, tj. do Zábřehu i do Hrabové, do dopravního komunálního podniku došlo v roce 1953. Teprve od této chvíle lze hovořit o ucelené a jednotné ostravské dopravní síti, kterou však již obstarával Oblastní dopravní komunální podnik Jednotného národního výboru v Ostravě. ${ }^{105}$

\section{Závěr}

Vznik ostravského dopravního komunálního podniku představoval komplikovaný proces, v němž se z původně samostatných dopravních firem staly „pouze“ jeho části. Ukázalo se, že samotný proces vzniku a tvorby komunálního podniku narazil na komplikace spojené s odlišným výkladem znárodňovaných dekretů, na řevnivost mezi jednotlivými složkami lidové samosprávy i na obtížné majetkové vztahy vyvolané okupací. Postupné zapojování jednotlivých dopravních firem vyžadovalo dlouhodobé a několikastupňové vyjednávání, jehož výsledek nemusel být jistý. Svou roli v tomto procesu sehrávala rovněž nejasná dopravní koncepce Ostravska, v níž spolu soutěžily autobusová a tramvajová doprava. V souvislosti s Ostravskem došlo ke znárodnění pouze části jedné z dopravních firem, konkrétně autobusové dopravy Společnosti moravských místních drah. Tento nezákonný krok státních orgánů výrazně zkomplikoval proces tvorby ostravského komunálního podniku. Lidová správa byla nucena podstoupit komplikovaný a časově náročný proces začleňování znárodněného majetku do komunálního podniku.

V př́ípadě začleňování majetku Slezských zemských drah panovaly nejasnosti v otázce vlastnictví jednotlivých tratí a negativně do jednání vstoupil rovněž zákon o krajském zřízení, který likvidoval dosavadní zemské zrrízení a vytvořil právní nejistotu ohledně vlastnictví zemských dopravních podniků. Zřejmě z tohoto důvodu bylo také upuštěno od zrrízení krajského dopravního podniku a majetek bývalé země byl se souhlasem ministerstev a Krajského národního výboru převeden do vznikajícího ostravského dopravního podniku. Poslední podnik - závodní dráhy Vítkovických železáren Klementa Gottwalda - byl začleněn do dopravního komunálního podniku až v roce 1953. Př́ičinou byla skutečnost, že tyto dráhy byly prohlášeny za strategické z hlediska průmyslového charakteru a vyňaty z procesu vzniku dopravního podniku. Lidová správa tak byla nucena vést dlouholeté vyjednávání, které naráželo na neochotu vedení strojírenského komplexu. Vítkovické železárny Klementa Gottwalda využívaly tyto dráhy primárně pro přepravu vlastních zaměstnanců, měly stanoven vlastní tarif a vybavení potřebné k provozu tratí se nacházelo na jejich pozemcích v areálu továren, kam vedení firmy odmítalo pouštět zaměstnance jiných podniků. Teprve na nátlak ministerstva a Krajského národního výboru bylo jednání z hlediska dopravního podniku úspěšné.

\footnotetext{
103 Patrná je tato frustrace ze zápisu o poradě svolané ministerstvem vnitra dne 17. 3. 1952. Tamtéž, fond JNV, inv. č. 1174, kart. 599.

104 Tamtéž, fond DPO, nezprac., kart. 170; tamtéž, fond JNV, inv. č. 1084, kart. 488.

105 Tamtéž, fond JNV, inv. č. 1174, kart. 599;Zákon č. 167/1950 Sb., zákon ze dne 20.prosince1950, okomunálních podnicích. Online, cit. dne 30.5.2020, https://www.epravo.cz/vyhledavani-aspi/?Id=25490\&Section=1 \& IdPa$\mathrm{ra}=1 \&$ ParaC $=2$.
} 
Je však zřejmé, že po celé sledované období, tj. od roku 1945, se městská doprava potýkala s ekonomickými problémy danými nejen válečnými událostmi, ale také nereálnými požadavky dvouletého a prvního pětiletého plánu, s masovým př́livem obyvatel spojeným s výstavbou ocelového srdce republiky apod. Stávající dopravní sít se stále zřetelněji dostávala na hranici svých možností a bylo zřejmé, že bez zásadních změn se město neobejde. Jeden z klíčových impulsů v úvahách o přestavbě stávajících tratí přinesl plán výstavby nové - socialistické - Ostravy. S ním ostravský dopravní komunální podnik vstoupil do nové éry plánování, jehož rozbor si však vyžaduje další archivní výzkum.

\section{Summary}

\section{Urban Rail Transport in Ostrava and the Establishment of a Municipal Transport Company (1945-1949)}

The establishment of the Ostrava municipal transport company was a complicated process during which the originally independent transport firms became „only“ parts of the new municipal enterprise. Analysing this process made it possible to monitor the application of legal norms after 1945 on a specific case. It was discovered that the process of establishment and creation of a municipal enterprise had encountered complications associated with different interpretations of the nationalization decrees, rivalry between various components of the administration and complicated property relations caused by the occupation. The gradual integration of the individual transport firms required long-term and multi-levels negotiations the result of which could not have been certain. The unclear transport conception of the Ostrava region, where bus and tram transport competed, also played a role in this process. In the Ostrava region, only a part of one transport company, namely the bus division of the Local Railway Company, was nationalized. This non-standard approach of the state significantly complicated the process of creating the Ostrava municipal transport company. The administration was forced to undergo a complicated and time-consuming process of incorporating nationalized property, including the requirement to pay for the property subject to nationalization.

In the context of incorporating the assets of the Silesian Provincial Railways, there were ambiguities in the ownership of the various tracks. Furthermore, the negotiations were negatively impacted by the Act on Regional Establishment which cancelled the existing provincial establishment and created legal uncertainty regarding the ownership of provincial transport companies. This is also probably why the establishment of a larger scale regional transport company was abandoned and the property of the former country was transferred to the emerging Ostrava municipal transport company with the consent of the ministries and the Regional National Committee. The final transport firm - the railway company of the Vitkovice Klement Gottwald Ironworks was incorporated into the municipal transport company as late as in 1953 because the railway was declared strategic in terms of the industrial character and excluded from the process of establishing a new municipal transport company. The administration was thus forced to conduct long-term negotiations with the reluctant management of the engineering complex. The Vitkovice Klement Gottwald Ironworks used the railway primarily to transport their own employees. They had their own tariffs set and the equipment needed to operate the railway was located on the ironwork's property inside the factory complex where the company's management refused to let employees of other companies. Only under pressure from the Ministry and the Regional National Committee were the negotiations successful. In spite of this process of creating a municipal transport company, it became clear that the Ostrava transport network was at the limit of its possibilities and its further operation would be possible only through fundamental restructuring and investment in modern transport solutions. 